\title{
MEDICINE AND THE LAW
}

\section{Corporal punishment in the home: Is there a legal duty on the medical doctor to report it?}

\author{
S Lutchman, LLB, LLM \\ Department of Public Law, Faculty of Law, University of Cape Town, South Africa
}

Corresponding author: S Lutchman (salona.lutchman@uct.ac.za)

The infliction of corporal punishment on children (in the home) was found to be unconstitutional by the Constitutional Court of South Africa (September 2019). Corporal punishment was historically permitted if exercised within reasonable grounds (moderate or reasonable chastisement). In reaching its judgment, the apex court found that the child's right to human dignity and to be free from all forms of violence was unjustifiably infringed by the exercising of this form of discipline. In addition, the child's best interests was not served. Importantly, there were other non-violent means available to parents to discipline their children. This article examines what this judgment means for medical doctors who reasonably suspect that a child has been the victim of corporal punishment. It is argued that medical doctors have a duty to report such incidents in terms of section 110(1) of the Children's Act 38 of 2005.

S Afr Med J 2021;111(7):620-622. https://doi.org/10.7196/SAMJ.2021.v111i7.15528

Corporal punishment or reasonable chastisement has a long and cruel history in South Africa (SA). Used as a form of corrective discipline since time immemorial, it has been used to inflict intentional violence on certain members of society. Over the course of time, SA has abolished the punishment in its varied contexts, finding it to infringe numerous human rights. ${ }^{[1,2]}$ In September 2019, the SA Constitutional Court held in the Freedom of Religion South Africa (FORSA) judgment ${ }^{[3]}$ that corporal punishment inflicted by parents (including guardians and caregivers) on their children was unconstitutional. With this judgment, corporal punishment has finally been completely eradicated from the SA law books.

While this judgment should be lauded as being an important step in eliminating all forms of violence against children, it is important to fully understand its implications. Unlike the abolishment of corporal punishment as a sentence imposed for convicted criminals, or the abolishment of corporal punishment in schools, the abolishment of corporal punishment in the home seems to hit many sensitive nerves. In fact, if the court was bound by public opinion, the judgment would probably have been very different. The central opposing argument is this: corporal punishment or reasonable chastisement, when done within bounds of reasonableness, is a loving and effective means for parents to discipline their children. ${ }^{[3]}$ Further arguments hold that it is religiously sanctioned. ${ }^{[3,4]}$ Why then should the state intervene in the privacy of the home and in the intimacy of the delicate parent-child relationship? If corporal punishment is religiously sanctioned by religious laws, why should transient man-made laws be obeyed? In any event, how will this ban be practically implemented? Despite the finality of the apex court's judgment, the arguments are ongoing. ${ }^{[2,5,6]}$

This article considers whether the FORSA judgment has implications for medical doctors. Doctors are ethically and legally obligated to act in the child's best interests. ${ }^{[7]}$ It is argued that the FORSA judgment creates an additional duty for medical doctors - as the advocates for child health - to intervene when a child suffers corporal punishment in the home.

To begin, I briefly consider the facts of the judgment and its progression through the court system, and then turn to whether the judgment places an obligation on medical doctors to report an incidence of corporal punishment.

\section{FORSA judgment}

This case began in the Johannesburg Regional Magistrate's Court. The accused was charged with two charges of assault with intent to do grievous bodily harm. The complainants in the matter were his wife and son. He was found guilty on both charges and was granted leave to appeal the convictions. He appealed to the Johannesburg High Court, Gauteng Local Division. ${ }^{[4]}$

The argument raised by the accused was that the assault on the child, a 13-year-old boy, was done in terms of moderate or reasonable chastisement. A parent historically had a right to use corporal punishment as a means of corrective discipline, provided it was not excessive and was done within reasonable means. Essentially, reasonable chastisement is a defence to a charge of assault. The physical force used (of whatever method) must have been for disciplinary purposes only. In this case, the father alleged that he physically chastised the child for viewing pornographic material.

Reasonable chastisement did not mean that the parent had complete discretion to inflict force on the child. The law provided certain parameters within which corporal punishment could be legally meted out. The factors to be considered were: the nature of the child's disciplinary infraction; the motive of the person administering the punishment; the degree of force applied; the object used to administer the punishment; and the age, sex and build of the child. ${ }^{[4]}$ It is these factors that sought to add structure to the reasonableness requirement. If the force met the reasonableness/ moderate requirement and if it was applied by a parent for disciplinary purposes, then what would ordinarily be deemed to be assault would be viewed within the general umbrella of the parent's right to discipline her child. ${ }^{[3]}$

The High Court concluded that a range of constitutional rights were implicated by the common law rule. The rights infringed were: the right to human dignity (section 10); the right to equal protection under the law (section 9(3)); the right to be free from all forms of 
violence from either public or private sources (section 12(1)(c)); the right not to be treated or punished in a cruel, inhuman or degrading way (section 12(1)(e)); the right to be protected from maltreatment, neglect, abuse or degradation (section 28(1)(d)); and the best interests of the child principle (section 28(2)). ${ }^{[4]}$ Consequently, the High Court found that the defence of moderate or reasonable chastisement was unconstitutional.

The judgment was taken on appeal by FORSA (who was a friend of the court or the amicus curiae in the High Court) to the Constitutional Court. Hearing an appeal brought in these circumstances is not the norm, but the court decided that it would hear the matter as it would be in the interests of the public to do so.

The Constitutional Court ultimately dismissed the appeal and upheld the High Court's ruling. In doing so, the court highlighted a few important aspects:

- The judgment was important to all parents, as parents discipline their children on a daily basis and so clarity on the issue was imperative.

- The constitutional right to be free from violence, from public and private sources, extended to all forms of violence and not only certain types of violence. This means that even the slightest form of corporal punishment falls within the net of prohibited conduct.

- Human dignity is a cornerstone of our constitutional democracy and the infliction of corporal punishment, however slight, aimed to impair the dignity of a child.

- Crucially, the infliction of corporal punishment was not proved to the court to serve the best interests of the child.

- The limitation of the child's right to dignity and to be free from all forms of violence could not be justified since reasonable chastisement could not be proved to be beneficial to the child. In addition, there were less restrictive means to achieve the same purpose, i.e. non-violent parenting methods.

\section{Is there a legal duity on the doctor to intervene?}

What does the FORSA judgment mean for medical doctors who suspect that a child has been inflicted with corporal punishment at home?

Children are right holders. The Constitution and the Children's $\mathrm{Act}^{[8]}$ provide children with a suite of rights, the most foundational being that the best interests of the child is of paramount importance in every matter regarding the child. In addition to the best interests principle, the Constitutional Court in FORSA has singled out particular rights that bear crucial importance. The first is that the child has freedom and security of person, which entails a right to be free from all forms of violence, whether enforced by public or private sources. Furthermore, the child's dignity is to be respected.

Medical doctors currently have certain statutory reporting duties in relation to children who have been abused. In terms of section 110(1) of the Children's Act, if a medical doctor reasonably believes that a child has been abused in a manner causing physical injury, sexual abuse or deliberate neglect, she must report that conclusion in the prescribed form (Form 22) to a designated child protection organisation, the provincial department of social development or a police official. If the report has been made in good faith, the medical doctor cannot be sued in court on the basis of the report. However, if one fails to make the report when there are reasonable grounds to do so, there is the possibility of criminal sanctions.

Form 22 requires the following: details of the informant and the child; information providing evidence of the alleged abuse or neglect; the possible perpetrator and his/her identifying details; any previous history of abuse known to the informant; any prior children's court interventions; details of the circumstances in which the present abuse or neglect occurred; details regarding medical interventions; and previous social work interventions or police actions taken in relation to the abuser. There is quite a high threshold that must be satisfied - the medical doctor must complete the report on reasonable grounds, not a mere suspicion. This ensures that reports are limited to those cases where intervention from the authorities is actually required ${ }^{[9]}$ Medical doctors are not the only health professionals with such a duty. Dentists, midwives, nurses, occupational therapists, physiotherapists, psychologists, speech therapists, homeopaths and traditional health practitioners also bear this duty.

There is a high standard of proof - the reporter must reach the conclusion on reasonable grounds that abuse and/or neglect has occurred (my emphasis). This means that the medical doctor must have some evidence to show that the abuse or neglect has occurred. The duty to report is triggered when the prohibited conduct caused physical injury, sexual abuse or deliberate neglect. The Children's Act defines 'abuse' as:

'[ .... a]ny form of harm or ill-treatment deliberately inflicted on a child, and includes -

(a) assaulting a child or inflicting any other form of deliberate injury to a child;

(b) sexually abusing a child or allowing a child to be sexually abused;

(c) bullying by another child;

(d) a labour practice that exploits a child; or

(e) exposing or subjecting a child to behaviour that may harm the child psychologically or emotionally; .....

Would corporal punishment fall within the category of reportable conduct?

Given that the harm suffered by a child due to corporal punishment takes a physical form that potentially impacts the physical, psychological and emotional wellbeing of the child, it seems safe to assume that corporal punishment is a reportable conduct. Prior to the FORSA judgment, a doctor would not be bound to report a known incidence of corporal punishment, as the harm inflicted by the parent could be reasoned away as being corrective discipline or reasonable chastisement. Of course, if the doctor believed that the physical force inflicted was beyond the bounds of what would be considered reasonable, then the defence would fall away. Under these circumstances, the doctor was statutorily required to report the abuse to the relevant authorities.

However, it would seem that the FORSA judgment removes this spectrum of discretion given to the medical doctor. The Constitutional Court found that corporal punishment could not be justified, as it breached a child's right to human dignity and to be free from all forms of violence. In terms of the Children's Act, 'abuse' includes any form of harm or ill treatment deliberately inflicted on a child, whether causing physical injury or psychological or emotional harm. It would therefore be safe to conclude that if a medical doctor witnessed or suspected that a parent or guardian inflicted corporal punishment on a child, that doctor would be statutorily obliged to report such conduct.

Would it make a difference if the corporal punishment was only to a slight degree, i.e. a minor infraction? Here it would seem that the law is unclear. While the Constitutional Court has said that even the minutest of infractions still results in the conduct being unlawful, it may not result in the prosecution of the parent on the basis of the de minimis non curat lex principle (the law does not concern itself 
with trifles). This would seem to indicate that the reporting obligation remains (despite the degree of infraction) and the discretion to prosecute rests on the usual legal authorities. The only discretion to be exercised by the medical doctor is to determine if there are reasonable grounds to suspect that the corporal punishment has been inflicted.

\section{Conclusions}

Violence begets violence. In a society plagued by high levels of physical and sexual violence, it is important that a strong stance is taken against acts of violence. Corporal punishment inflicted against children has strong correlations with violence inflicted against women in the home. ${ }^{[10]}$ Indeed, what begins as the moderate infliction of violence more often than not results in long-term abuse. ${ }^{[5,10]}$ What is hoped is that the banning of corporal punishment in the home results in a change in parenting attitudes and not in the prosecution of parents. ${ }^{[10,11]}$ Medical doctors have a crucial role to play in advocating for the good health of children. The right to health is viewed holistically, as it is intrinsically linked to many other rights - human dignity, bodily integrity, and the best interests of the child principle. It is hoped that these important advocates will not turn a blind eye to these vulnerable patients when there are reasonable grounds to suspect the infliction of corporal punishment.
Declaration. None.

Acknowledgements. None.

Author contributions. Sole author.

Funding. None.

Conflicts of interest. None.
1. Skelton A. S v Williams: A springboard for further debate about corporal punishment. Acta Juridica 2015:336-359.
2. Sloth-Nielsen J. Sideswipes and backhanders: Abolition of the reasonable chastisement defence in South Africa. Int J Law Policy Family 2020;34:191-203. https://doi.org/10.1093/lawfam/ebaa005
3. Freedom of Religion South Africa v Minister of Justice and Others 2020 (1) SA 1 (CC) or 'FORSA
3. Freedom of Religion South Africa v Minister of Justice and Others 2020 (1) St
judgment.
4. S v YG 2018 (1) SACR 64 (GJ) (hereinafter referred to as 'S v YG judgment').
4. S v YG 2018 (1) SACR 64 (GJ) (hereinafter referred to as 'S v YG judgment').
5. Lenta P. Corporal punishment and the costs of judicial minimalism. S Afr Law J 2020;137(2):185-200 6. Clarke B. Why can't I discipline my child properly? Banning corporal punishment and its consequences. S Afr Law J 2020;137(2):335-359.
7. Constitution of the Republic of South Africa, 1996
8. South Africa. Act No. 38 of 2005 (hereinafter referred to as the 'Children's Act').
9. Sloth-Nielsen J. Chapter 7: Protection of children. In: Davel CJ, Skelton AM. Commentary on the Children's Act 7-23. Cape Town: Juta, 2007.
10. Freeman M, Saunders BJ. Can we conquer child abuse if we don't outlaw physical chastisement of children? Int J Child Rights 2014;22:681-709. https://doi.org/10.1163/15718182-02204002
11. United Nations Children's Emergency Fund. Women and Children. The Double Dividend of Gender Equality. New York: UNICEF, 2007.

Accepted 11 January 2021. 